\title{
ICE PROPERTIES IN THE GREENLAND AND BARENTS SEAS DURING SUMMER
}

\author{
By Søren Overgaard, \\ (Elektromagnetisk Institut, Danmarks Tekniske Højskole, DK2800 Lyngby, Denmark) \\ Peter Wadhams, \\ (Scott Polar Research Institute, University of Cambridge, Cambridge CB2 1ER, England) \\ and MATTI LEPPÄRANTA \\ (Merentutkimuslaitos, P.O. Box 166, SF-00141 Helsinki 14, Finland)
}

\begin{abstract}
The analysis of sea-ice cores from three summer field operations to the European Arctic is reported, and the ice properties are related to general conditions of ice distribution, thickness, and ridging in the experimental areas. The operations were in 1978 and 1979 to the Kong Oscars Fjord area of East Greenland (about lat. $72^{\circ}$ N.) and in 1980 to the Barents Sea, Fram Strait, and the Arctic Ocean north of Svalbard and Zemlya Frantsa Iosifa on the Swedish Ymer-80 expedition. Salinity profiles show the effect on multi-year floes of a year's additional confinement in a fjord, the effect of a month's desalination (July to August) on first-year and multi-year ice, and the difference between first-year and multi-year ice at the end of the melt season. The average salinity as a function of ice thickness agrees reasonably well with the results of Cox and Weeks (1974). Temperature, density, $\mathrm{pH}$, and ionic composition results are also reported, and the effect of brine volume on dielectric constant discussed.
\end{abstract}

RÉsumÉ. Propriétés de la glace au Groënland et dans la mer de Barentz durant l'été. On rapporte les résultats de l'analyse de carottes de mer de glace à partir de trois opérations d'été sur le terrain dans l'arctique européen, et les propriétés de la glace sont mises en rapport avec les conditions générales de la distribution de glace, leur épaisseur et leur relief dans la zone explorée. Les opérations eurent lieu en 1978 et 1979 dans la zone du Kong Oscars Fjord du Groënland oriental (environ lat. $72^{\circ}$ N.) et en 1980 dans la mer de Barentz, à Fram Détroit et l'Océan Arctique au nord de Svalbard et de la Zemlya Frantsa Iosifa lors de l'expédition suédoise Ymer-80. Des profils de salinité montrent l'effet sur des glaces flottantes pluri-annuelles d'une année supplémentaire de confinement dans un fjord; l'effet de la baisse annuelle de salinité (juillet et août) sur la glace de première année et sur la glace pluri-annuelle; et les différences entre la glace de première année et la glace pluri-annuelle à la fin de la saison de fusion. La salinité moyenne en fonction de l'épaisseur de la glace concorde raisonnablement bien avec les résultats de Cox et Weeks (1974). La température, la densité, le pH et les résultats de l'analyse ionique sont également rapportés et l'on discute l'effet du volume de la saumure sur la constante dielectrique.

Zusammenfassung. Eigenschaften des Meereises in der Grönland-und Barentssee während des Sommers. Es wird über die Analyse der Meereiskerne aus drei Sommerkampagnen in der europäischen Arktis berichtet. Die Eigenschaften des Eises werden zu den allgemeinen Bedingungen der Verteilung, Dicke und Rükenbildung des Eises im Untersuchungsgebiet in Beziehung gebracht. Die Kampagnen erstreckten sich 1978 und 1979 auf das Gebiet des Kong Oscars Fjord in Ost-Grönland (etwa $72^{\circ}$ N.) und 1980 auf die Barentssee, die Fram-Strasse und den Arktischen Ozean nördlich von Svalbard und Zemlya Frantsa Iosifa im Rahmen der schwedischen Ymer80-Expedition. Profile des Salzgehaltes zeifen an vieljährigen Schollen den Effekt eines einjährigen Einschlusses in einen Fjord den Effekt einer einmonatigen (Juli-August) Entsalzung an ein- und vieljährigen Eis und den Unterschied zwischen ein- und vieljährigen Eis am Ende der Schmelzperiode. Der mittlere Salzgehalt als Funktion der Eisdicke stimmt recht gut mit den Ergebnissen von Cox und Weeks (1974) überein. Ergebnisse der Messungen von Temperatur, Dichte, pH-Wert und Ionen-Zusammensetzung werden ebenfalls mitgeteilt; der Einfluss des Sole-Volumens auf die Dielektrizitätskonstante wird diskutiert.

\section{INTRODUCTION}

Recent reviews have drawn attention to the lack of data on the properties of sea ice from the 
Greenland Sea (Wadhams, 1981[a]; Weeks, 1982). Most ice cores that have been analysed have been drawn from the Beaufort Sea, and general conclusions about ice salinity have been based on these cores (Schwarzacher, 1959; Cox and Weeks, 1974). Now that ice properties work has begun in the Weddell Sea (Gow and others, 1982) some major bipolar differences in ice composition have been found, with Antarctic ice, for instance, containing a larger fraction of frazil ice than Beaufort Sea ice. The idea that all sea ice can be characterized from Beaufort Sea samples is therefore no longer tenable, and there is renewed interest in regional differences. In this paper we report on ice-core data and other ice observations from three summers of field work in the Greenland and Barents Seas and the European sector of the Arctic Ocean. In each case the ice properties measurements were not the primary purpose of the field experiments.

The first two seasons of work were carried out from Mestersvig, a Danish weather station on Kong Oscars Fjord, East Greenland (lat. $72^{\circ} 13^{\prime}$ N., long. $23^{\circ} 56^{\prime}$ W.). A chartered helicopter was used to visit floes in the fjord, at its mouth (Davy Sund) and along the nearby open coast between lat. $71^{\circ} 50^{\prime} \mathrm{N}$. and lat. $72^{\circ} 25^{\prime} \mathrm{N}$. The experimental periods were 2-29 September 1978 and 24 August-20 September 1979. The main purpose of the experiments was to measure wave decay through the ice cover, and the flexural and heave responses of floes to wave action (Wadhams, 1979; Wadhams and Squire, 1979; Overgaard, 1980; Goodman and others, 1980). Six cores were taken through multi-year ice in 1978, and seven cores through multi-year ice in 1979, in each case using a SIPRE corer with a barrel of $75 \mathrm{~mm}$ diameter. The positions of the cores are shown in Figure 1.

The third season of work was carried out aboard the Swedish icebreaker Ymer during the Ymer-80 cruise (Ymer, 1981), a multidisciplinary expedition to the European Arctic organized to commemorate the centenary of A. E. Nordenskiöld's transit of the North-east Passage aboard Vega. Figure 2 shows the route of the ship and the position of cores taken. Leg 1 (24 June to 6 August 1980) took her through the Barents Sea and into the Arctic Ocean north-east of Svalbard as far north as lat. $82^{\circ} 30^{\prime}$. A programme of coring, ice characterization, current measurements, and laser profiling was carried out by the University of Helsinki and the Merentutkimuslaitos (Institute of Marine Research), with preliminary results reported by Palosuo (1981[a]. [b]) and Leppäranta and Palosuo ([1981]). 19 cores were taken on this leg through a variety of ice types. Leg 2 (9 August to 24 September 1980) took Ymer over the same route and also westward across Fram Strait to north-east Greenland. Scott Polar Research Institute (S.P.R.I.) carried out an ice programme which included floe tracking by radar transponders, wave and current

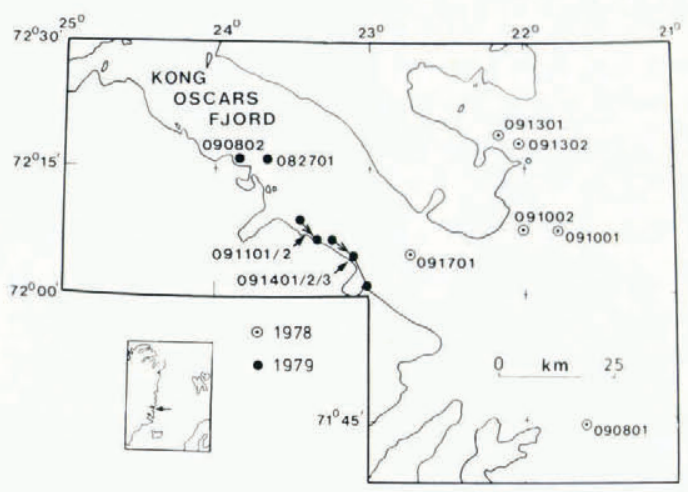

Fig. 1. The Kong Oscars Fjord area of east Greenland, showing locations of 1978 and 1979 cores and the drift tracks of two floes occupied for several hours in 1979. 


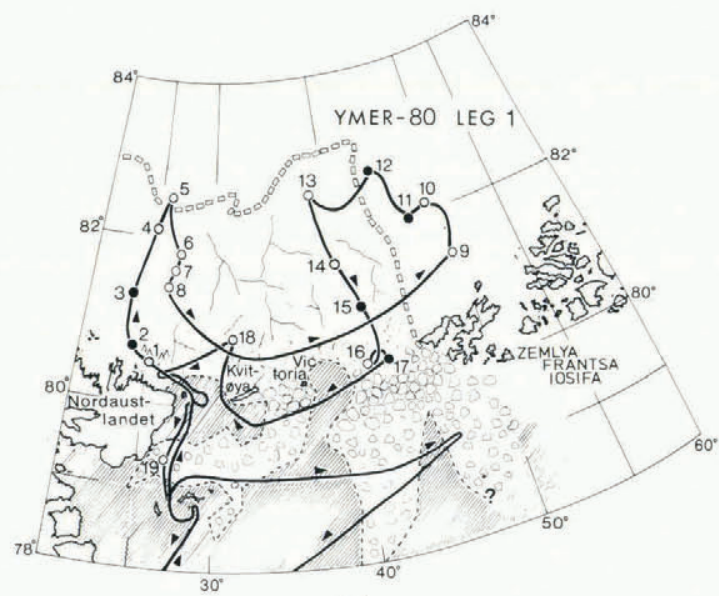

(a)

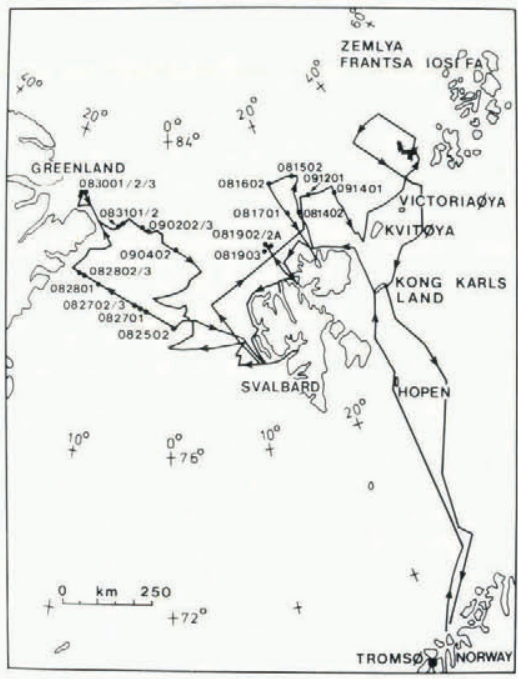

(b)

Fig. 2. (a) Locations of cores taken during leg 1 of Ymer-80, with an indication of ice concentration during July 1980. Dotted line is ice edge and barred line is approximate limit of multi-year ice. (b) Track chart of leg 2 of Ymer-80, showing locations of cores.

measurements, and ice coring. 25 cores were taken, partly to provide ground truth for a radar scatterometry experiment (Onstott and others, 1982). Thus the total data set for the three years consists of 57 cores.

\section{ICI: CONDITIONS IN THE SURVEY AREAS}

\subsection{East Greenland 1978}

In summer 1978 both Kong Oscars Fjord and the offshore zone outside it carried a drift ice cover, the southern East Greenland ice limit lying between lat. $70^{\circ} 30^{\prime} \mathrm{N}$. (Scoresbysund) and lat. $71^{\circ} \mathrm{N}$. throughout the experimental period. The ice concentration was typically $6-8 / 10$, composed of floes of diameters $30-120 \mathrm{~m}$ in an intimate mixture of first-year and multi-year ice. The median diameter (across longest axis) of 22 floes visited was $45 \mathrm{~m}$, and most floes lay in the range 30-60 m. Multi-year floes were extensively hummocked, with a snow cover of $1-2 \mathrm{~cm}$ and large areas covered by refrozen melt pools. The mean thickness of 14 measurements through smooth areas was $3.1 \mathrm{~m}$, which underestimates the true mean. First-year floes were smoother and averaged $1.5 \mathrm{~m}$ in thickness. The water surface between the floes was filled by brash and, later in September, newly formed pancake ice and sheets of nilas.

Figure 3 shows a Landsat image taken on 18 September 1978 and is typical of ice conditions during the experiments. A gyre is clearly visible within the fjord, showing that the surface circulation consists of an inflow along the north side of the fjord; a gyre within the fjord where incoming East Greenland Current water entrains ice-free fjord surface water; and an outflowing jet of fjord water along the south side of the fjord. This circulation pattern was first mentioned by Koch (1945) who stated that Kong Oscars Fjord and Scoresbysund are the only East Greenland fjords wide enough to possess such an internal surface circulation; Koch illustrated the 


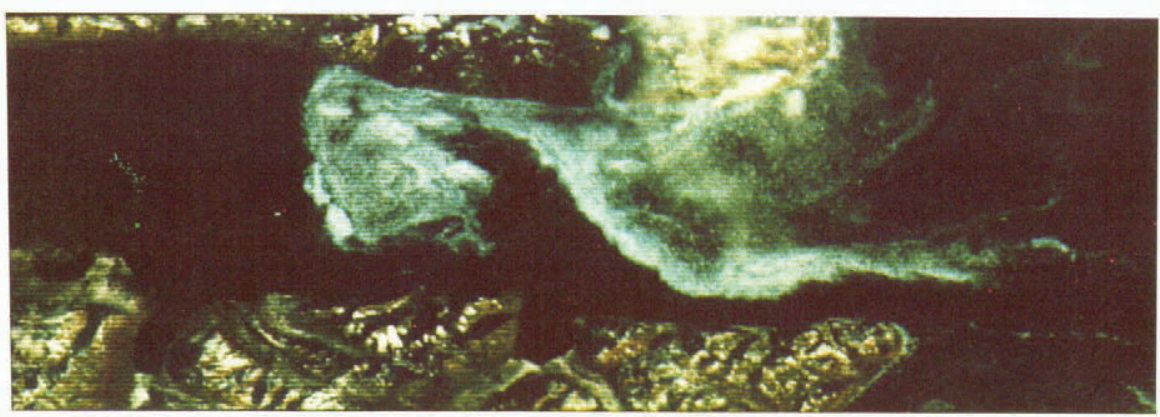

Fig. 3. A Landsat-3 image of Kong Oscars Fjord taken on 18 September 1978. The image is a sum of spectral bands $4(0.5-0.6 \mu \mathrm{m}), 5(0.6-0.7 \mu \mathrm{m})$ and $7(0.8-1.1 \mu \mathrm{m})$ with enhancement on the DK.IDIMS digital image computer at Electromagnetics Institute.

Scoresbysund pattern (reproduced in Wadhams, 1981[a]) which closely resembles that of Figure 3. Within the ice-covered zone the sea surface temperature was close to freezing point, varying from $-1.1^{\circ} \mathrm{C}$ to $-1.9^{\circ} \mathrm{C}\left(-1.62^{\circ} \mathrm{C}\right.$ was the mean of 18 measurements), and water samples taken to $25 \mathrm{~m}$ depth by a Van Dorn bottle showed that the water column was isothermal to that depth. Air temperatures during the day on the ice ( 10.00 to $18.00 \mathrm{~h}$ local time) varied within the narrow range -3 to $+1{ }^{\circ} \mathrm{C}$ (mean $-1.2^{\circ} \mathrm{C}$ ) with winds usually very light (mean of $1.1 \mathrm{~m} \mathrm{~s}^{-1}$, maximum of $7 \mathrm{~m} \mathrm{~s}^{-1}$ and $60 \%$ calm). Surface melting had lowered the surface water salinity to a mean of $21.7 \%$ within the ice zone (13 measurements varying from $15.7 \%$ o to $27.5 \%$ ) while at $25 \mathrm{~m}$ the salinity reached $31.6 \%$.

\subsection{East Greenland 1979}

Conditions in the same area in 1979 were quite different. At the time of freeze-up in autumn 1978 a large amount of ice from the main East Greenland pack remained in Kong Oscars Fjord and became embedded in the fast ice cover which formed in the fjord. Wadhams (1981[a], fig. 14) shows Tiros- $\mathrm{N}$ imagery from 22 July 1979 when the fast-ice cover was still complete together with a fringe of fast ice along the outer coast. Fast-ice break-up began in early August but was incomplete in that a "plug" of fast ice remained to block the mouth of Davy Sund until about 20 August, by which time the main pack had retreated north of the fjord mouth. When we arrived on 24 August the plug had broken up but its fragments remained as a coherent mass of floes at the mouth of Davy Sund. There was no offshore pack, while within Kong Oscars Fjord the ice consisted mainly of multi-year floes which had been trapped in the fjord all winter. Figure 4 shows two temperature, salinity, and $\mathrm{pH}$ profiles taken by Van Dorn bottle in the uppermost $15 \mathrm{~m}$ of fjord water on 30 and 31 August. The surface water was exceptionally warm and of low salinity from ice melt and run-off from land. Under these conditions the old floes in the fjord had become rotted and were heavily undercut around the waterline with active melt-water pools and thaw holes. Figure 5(a) is a side-looking airborne radar (SLAR) image of the fjord taken on 6 September using a Twin Otter of the Greenland Ice Patrol and a $10 \mathrm{GHz}$ SLAR developed at the Electromagnetisk Institut. The remains of the plug are still in place in Davy Sund (right of picture) while the remainder of the fjord contains a 3/10 ice cover with a few patches of greater density. By 10 September (Fig. 5(b)) the plug had disappeared, Davy Sund was ice-free, and a circulation similar to that of 1978 had begun to develop in the fjord. Figure 1 shows the tracks of 


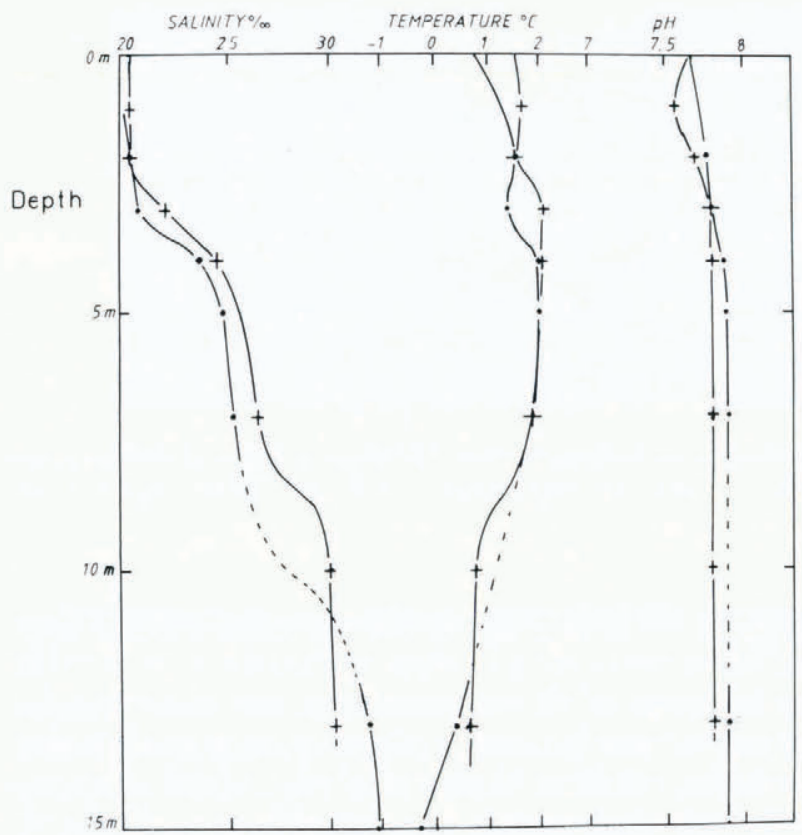

Fig. 4. Temperature, salinity, and $\mathrm{pH}$ profiles from the uppermost $15 \mathrm{~m}$ of water in Kong Oscars Fjord off Mestersvig, taken on 30 August (•) and 31 August (+) 1979.

two floes on which we worked for extended periods, showing outward drift along the south side of the fjord at some $0.5 \mathrm{~m} \mathrm{~s}^{-1}$. Time-lapse photography from a mountain on the south shore revealed an up-fjord drift near the north shore at a similar speed. This circulation rapidly drained the fjord of ice, since no new ice was entering from offshore. By 17 September the fjord was almost empty of ice and only on 20 September, our day of departure, did the pack advance southward and begin to enter the fjord again.

Winds during the period were again light, with $56 \%$ of the time calm, a mean of $1.4 \mathrm{~m} \mathrm{~s}^{-1}$ and maximum of $6.2 \mathrm{~m} \mathrm{~s}^{-1}$. Figure 6 is a wind rose showing that for most of the time the wind blew straight up the fjord. Air temperatures varied from $-6^{\circ} \mathrm{C}$ to $+7^{\circ} \mathrm{C}$ during the period from 06.00 to $18.00 \mathrm{~h}$ (mean $+0.5^{\circ} \mathrm{C}$ for period).

Ice thicknesses could not be determined because the rotted nature of the ice caused the corer to become stuck beyond about $1.5 \mathrm{~m}$. One multi-year floe, possibly a piece of broken-out sikussak (Walker and Wadhams, 1979) had a freeboard of $2.5 \mathrm{~m}$ and was honeycombed with vertical holes of small diameter $(1-2 \mathrm{~cm})$. Floe diameters were similar to 1978 .

\subsection{Barents Sea and north-east of Svalbard, 1980}

In the western Barents Sea the ice extent in the summer of 1980 was close to the 1971-1980 average, but in the eastern part more ice than normal occurred (Norsk Meteorologisk Institutt, 1980; Vinje, 1981). During late June much ice had drifted into the Barents Sea from the Arctic Basin, leaving wakes behind islands (Fig. 7), and by the beginning of July the ice edge lay between lat. $77^{\circ} \mathrm{N}$. at Svalbard and about lat. $75^{\circ} \mathrm{N}$. at Novaya Zemlya. During July the eastern Barents Sea opened up as far as Zemlya Frantsa Iosifa.

Ice in the Barents Sea was about $90 \%$ first-year during Ymer-80. Ice concentration varied greatly, with large areas of diffuse ice cover where the ice was in free drift and was in an 


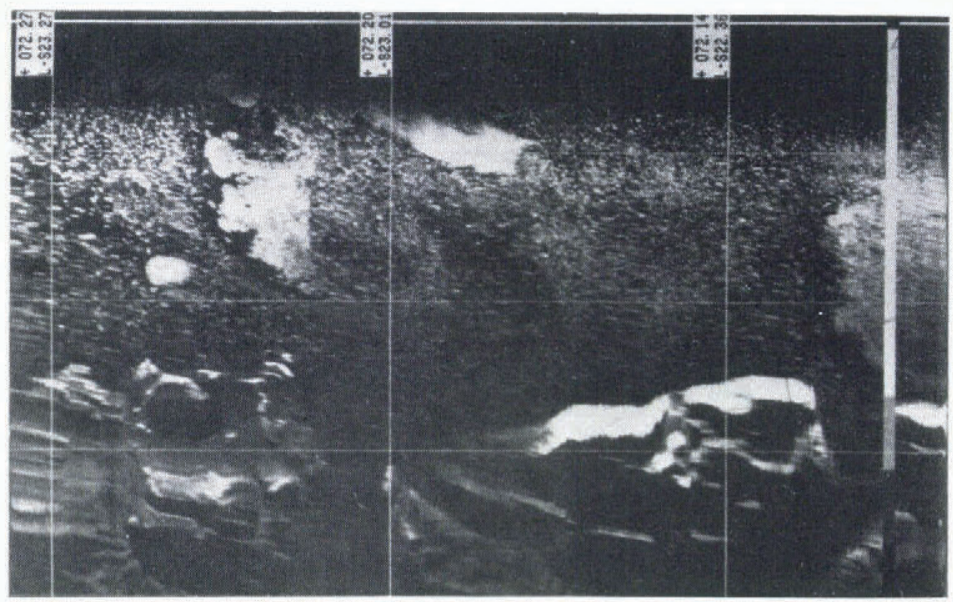

(a)

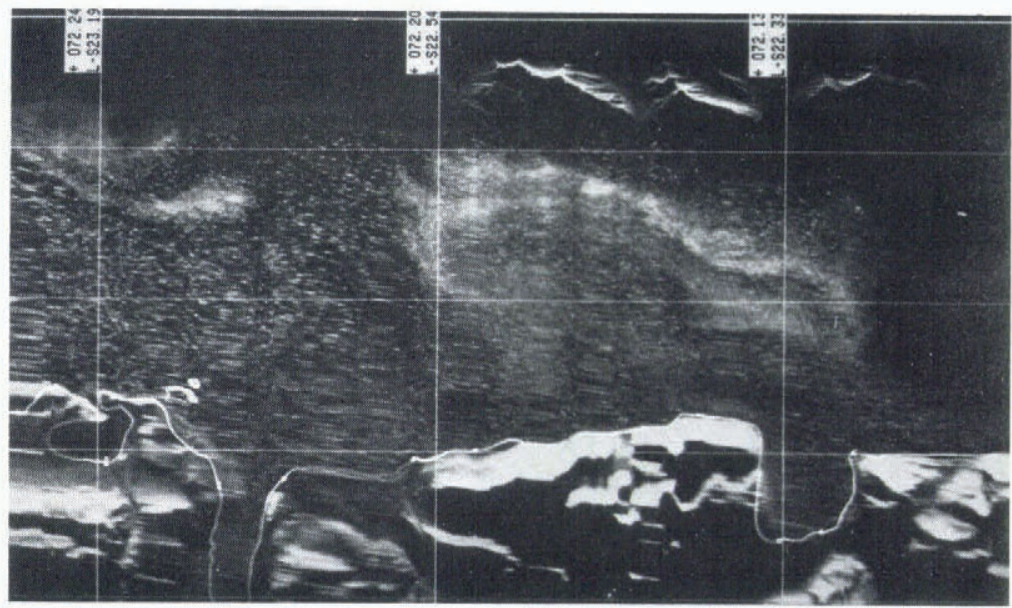

(b)

Fig. 5. Imagery of Kong Oscars Fjord taken by the $10 \mathrm{GHz}$ TUD side-looking airborne radar (SLAR) on (a) 6 September, (b) 10 September 1979, showing disappearance of dense mass of ice floes from Davy Sund. The flight altitude was $2700 \mathrm{~m}$ and the coastline has been enhanced in (b).

advanced stage of melting. North of the line Svalbard-Kvitøya-Zemlya Frantsa Iosifa the ice concentration increased beyond $8 / 10$ and the percentage of multi-year ice also increased (Fig. 2(a)). Multi-year ice was dominant north of lat. $82^{\circ} \mathrm{N}$. off Svalbard and north of lat. $81^{\circ} \mathrm{N}$. off Zemlya Frantsa Iosifa.

Ice cores gave only a few observations of floe thickness, and additional data were obtained on passage by scaling overturned ice blocks against a pair of marks on Ymer's weather deck (Fig. 8). In this way the mean floe thickness within the Barents Sea was estimated at 0.9-1.2 $\mathrm{m}$ (Fig. 9). Floe thickness increased in the Arctic Basin and exceeded 1.5-2 m north of the line where multi-year ice became dominant.

Ice surface topography was profiled with a Eumig laser mounted on Ymer's bridge and 


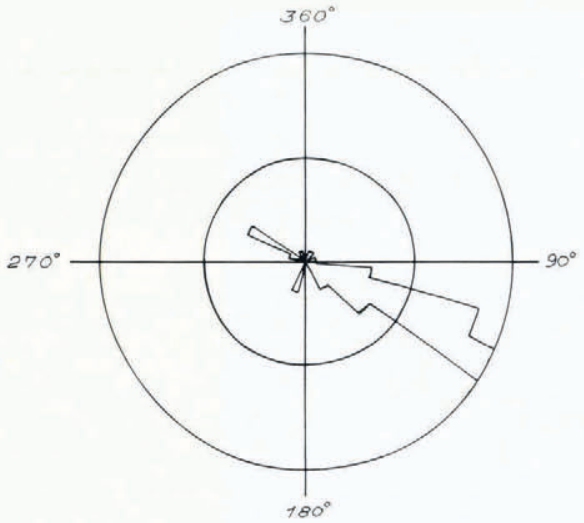

Fig. 6. Wind rose for Mestersvig, 27 August-17 September 1979.

aimed obliquely at the ice surface $30 \mathrm{~m}$ from the ship's side (Leppäranta and Palosuo, [1981]). The method was usable in first-year ice where ice thickness was less than $1.5 \mathrm{~m}$. In heavier ice the ship's motion was uneven, producing large uncertainties in the record. Further, in heavy ice $Y$ Ymer's route was chosen carefully to avoid large ridges and highly deformed floes. Owing to

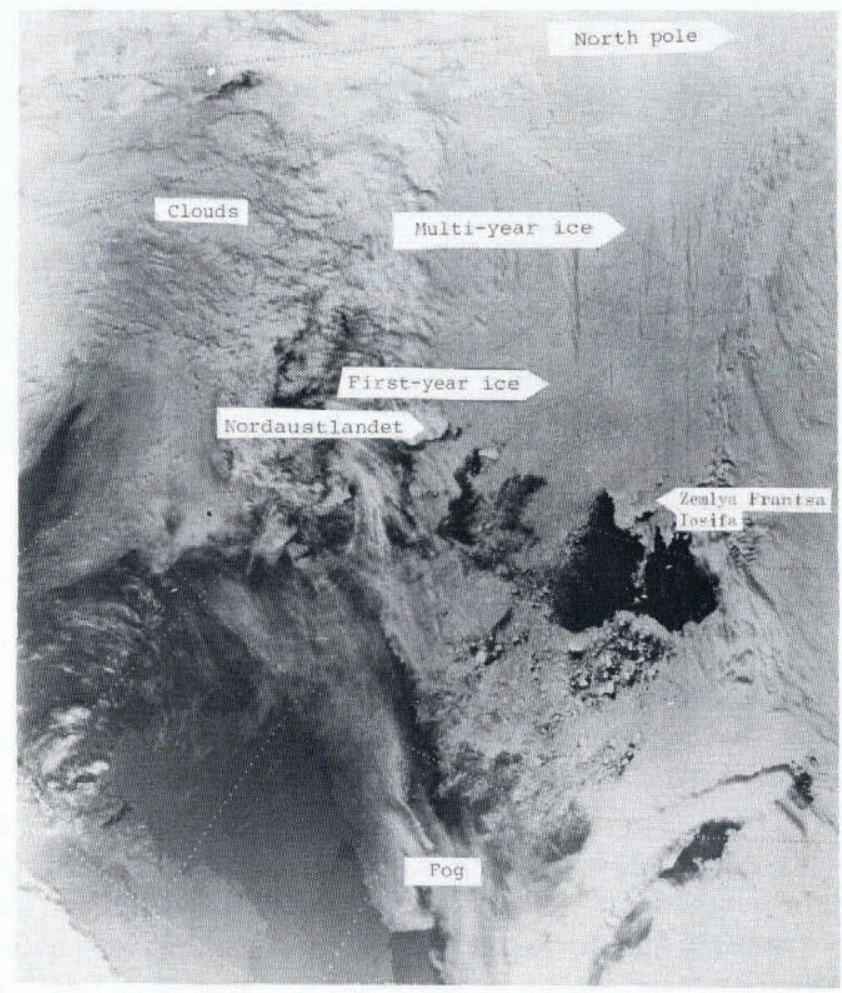

Fig. 7. NOAA-6 image of the Barents Sea and western Eurasian Basin, 26 June 1980, showing ice streaming into northern Barents Sea across Nordaustlandet-Zemlya Frantsa Iosifa axis. 


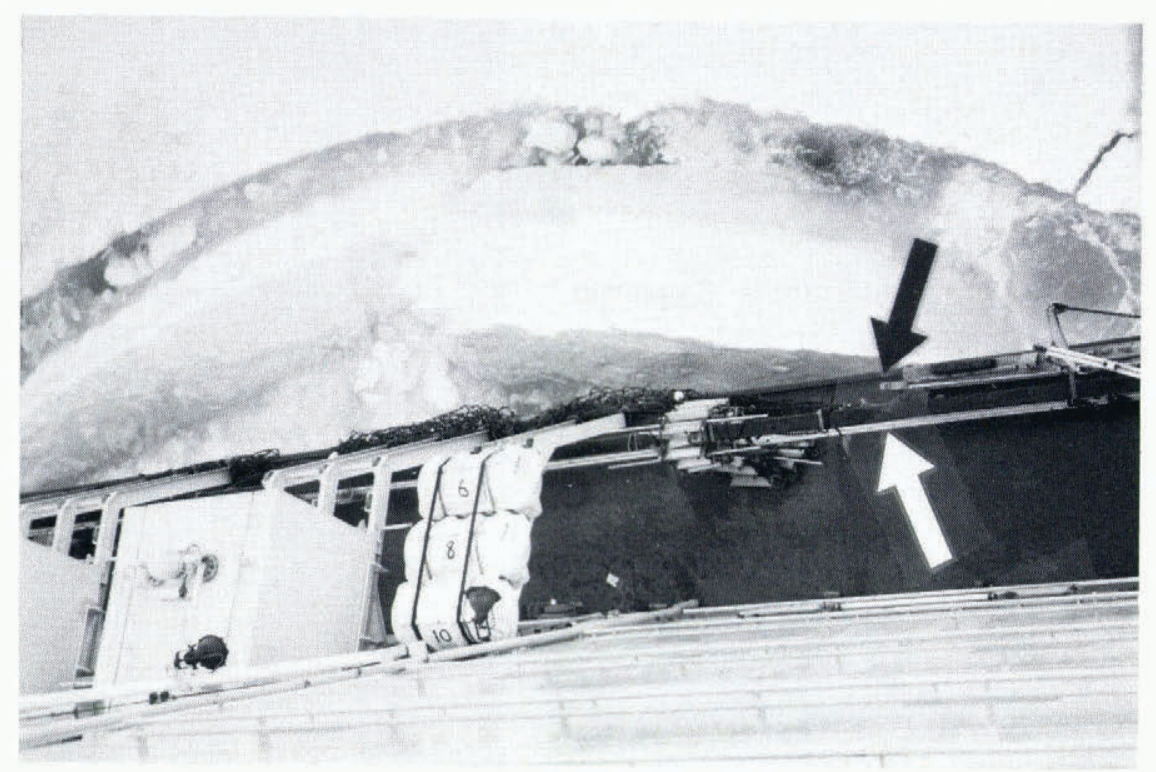

Fig. 8. The weather deck of Ymer, photographed from bridge, showing scale used to estimate thickness of overturned ice blocks (60 $\mathrm{cm}$ wide).

problems with the laser, measurements could not be made in the eastern Barents Sea nor during leg 2 . The usable data cover the early part of leg 1 , from Kong Karls Land to lat. $82^{\circ} \mathrm{N}$. Ridges appeared as narrow peaks in the plotted laser profiles and they were manually tabulated using a cutoff height of $0.9 \mathrm{~m}$. The results did not indicate significant variations over the study area, so all the profiles were combined in one distribution. Total path length was $72 \mathrm{~km}$ and 183 ridges were counted, a mean density of $2.6 \mathrm{~km}^{-1}$ ( $\pm 30 \%$ due to uncertainty in ridge identification). The mean sail height was $1.34 \mathrm{~m}$ and the height distribution (Fig. 10) did not differ significantly from a negative exponential. When converted to a $1 \mathrm{~m}$ cutoff these figures become $1.44 \mathrm{~m}$ mean and 2.1 sails per $\mathrm{km}$, which are lower than comparable values from further north in the western Eurasian Basin (Wadhams, 1981[b], fig. 20). Visual observations from the bridge gave a similar range of ridge heights but a larger ridge density in the northern areas, by a factor of 1.5 . This may be due to visual bias or to navigation. In the area north of Zemlya Frantsa Iosifa, not profiled by laser, ridges were higher and extensive hummock fields were seen.

The contribution to the mean ice thickness from ridged ice, $h_{\mathrm{e}}$, can be estimated from

$$
h_{\mathrm{e}}=10 \pi \mu \overline{h_{\mathrm{s}}^{2}}
$$

(Hibler and others, 1974), where $\mu$ is the number of ridges per kilometre and $\overline{h_{\mathrm{s}}^{2}}$ is the mean square sail height $\left(\mathrm{m}^{2}\right)$. The result is $h_{\mathrm{e}}=0.17 \mathrm{~m}$, i.e. about $15 \%$ of the level ice thickness. This depends on the choice of cutoff height; assuming that the negative exponential distribution for sail heights fits below $0.9 \mathrm{~m}$, a reduction of cutoff to $0.5 \mathrm{~m}$ increases $h_{\mathrm{e}}$ to $0.25 \mathrm{~m}$. This is similar to values estimated by Hibler and others (1974) for the Beaufort-Chukchi province of the Arctic Basin in summer, but lower than their values for the rest of the Arctic Basin. Hibler (1980) has also given mean thickness contours for the Arctic Ocean, estimated from submarine sonar surveys. North of Nordaustlandet his $2 \mathrm{~m}$ contour occurs at lat. $81.5^{\circ} \mathrm{N}$. in April; our July data, 


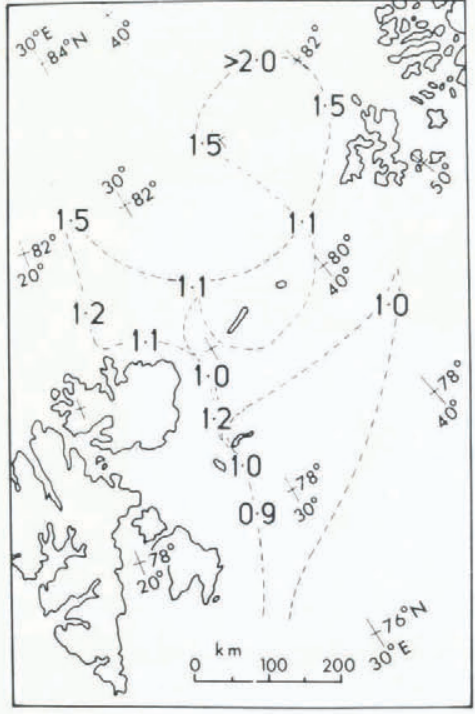

Fig. 9. Mean thickness of undeformed ice floes during leg 1 of Ymer-80, in metres.

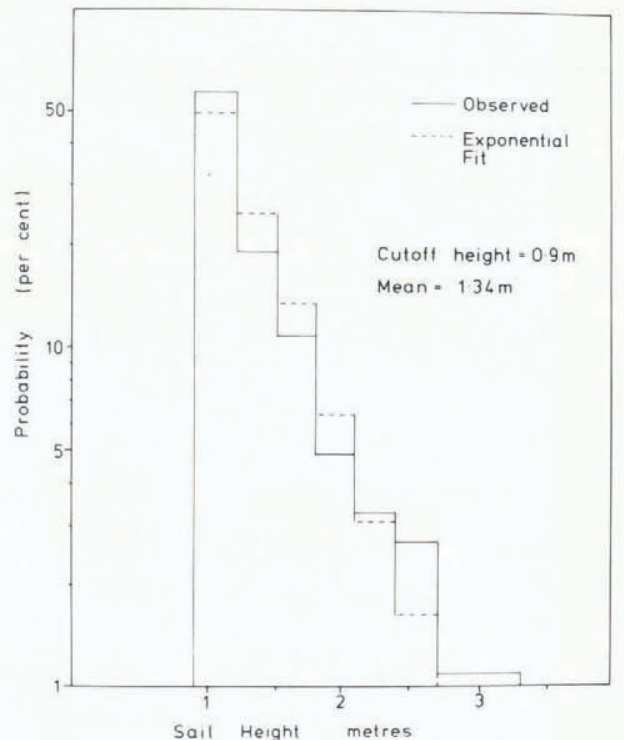

Fig. 10. Distribution of ridge sail height measured by laser during leg 1 of Ymer-80, showing fit to a negative exponential distribution. Track ran from Kong Karls Land to lat. $82^{\circ} \mathrm{N}$. long. $25^{\circ} \mathrm{E}$.

combining level ice and ridges, suggest a $1.5 \mathrm{~m}$ mean thickness at that latitude with a gradient of 0.2 to $0.3 \mathrm{~m}$ per degree of increasing latitude.

A number of icebergs were observed in the Barents Sea during Ymer-80 (Fig. 11). Zubov

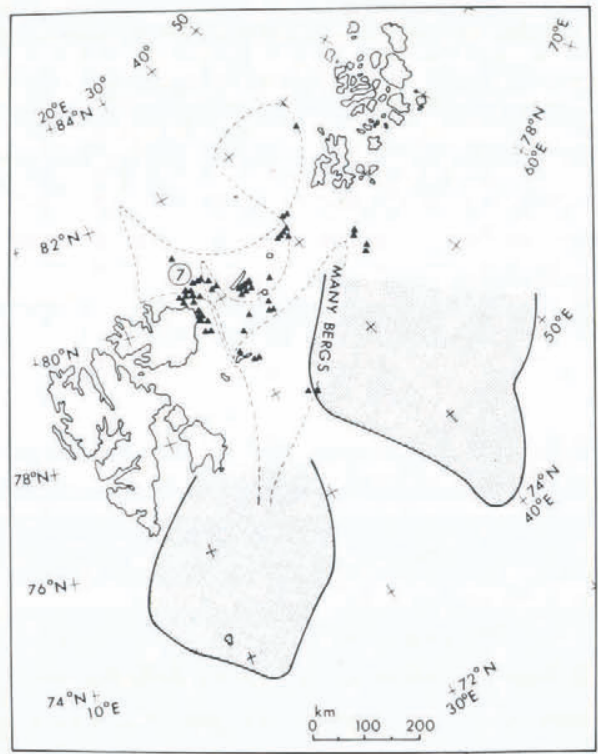

Fig. 11. Iceberg sightings during leg 1 of Ymer-80; the " 7 " indicates seven bergs together. Shaded areas are locations of grounded iceberg sightings during 1899-1928, according to Zubov (1945). 
(1945) reported that two areas of the Barents Sea (shaded in Fig. 11) were prolific sources of grounded iceberg sightings during the period 1899-1928. He believed that the eastern group of bergs originated from Zemlya Frantsa Iosifa and the western group from Nordaustlandet. Storøya, Kvitøya, and Victoria Island.

\subsection{Fram Strait, 1980}

Ymer crossed the ice edge in Fram Strait at lat. $79^{\circ} 15^{\prime}$ N., long. $00^{\circ} 38^{\prime}$ E., encountering conditions typical of the marginal ice zone (Wadhams, 1980, 1981[a]), i.e. a well-defined ice edge fringed by small floes (less than $30 \mathrm{~m}$ diameter), with the floe size gradually increasing with distance from the edge until heavy consolidated pack ice began some $40-60 \mathrm{~km}$ inside the ice edge. Although well-defined, the edge was subject to meanders and, at the point of entry, a large vortex some $60 \mathrm{~km}$ in diameter caused by an instability of the front between polar surface water and Greenland Sea water (Wadhams and Squire, in press). Six small icebergs were also seen at the ice edge (Wadhams, 1981[a], fig. 21).

The ice in Fram Strait was an intimate mixture of first- and multi-year ice at 10/10 concentration. Near the Greenland coast, however, a zone of open water was encountered, which extended from the point of entry (lat. $80^{\circ} 40^{\prime} \mathrm{N}$.) up to Nordøstrundingen. This polynya is characteristic of the region, and has been discussed in Wadhams (1981[a]). Large tabular icebergs, possibly calved from Flade Isblink, were observed along the coast (Wadhams, 1981|a|, fig. 23). North of Nordøstrundingen a narrower lead continued to run north-west separating the offshore pack from very old multi-year fast ice at the mouth of Danmarks and Independence Fjords. This lead closed at lat. $82^{\circ} 25^{\prime} \mathrm{N}$., long. $16^{\circ} \mathrm{W}$, and very heavy deformed pack ice was encountered, forcing $Y$ mer to return to the south-east.

\section{Salinity variations in SEa ice}

\subsection{Technique}

As each ice-core section was drawn, it was encased quickly in a mould consisting of a vertical Teflon-lined cylinder cut lengthways and enclosed in an insulated wooden frame. The mould was perforated with holes at $10 \mathrm{~cm}$ intervals, into which a digital thermometer probe was pushed. The core was then placed in a second frame and sawed into $10 \mathrm{~cm}$ sections, which were measured with calipers, weighed and placed in bottles. After melting in the laboratory (ship or hut) and warming to ambient temperature, the conductivity was measured with a bench salinometer (1978/9), a conductivity probe which was frequently recalibrated against standard salinity samples (1980, leg 2) or a vibration density meter, with the salinity calculated from density (1980, leg 1).

When salinity was calculated from conductivity, the standard relation of UNESCO (1971) was used:

$$
S=-0.08996+28.2972 R+12.80832 R^{2}-10.67869 R^{3}+5.98624 R^{4}-1.32311 R^{5}(2)
$$

where $S$ is salinity in \%o and $R$ is the ratio of sample conductivity to the conductivity of standard sea-water (chlorinity $19.376 \%$ ) at $15{ }^{\circ} \mathrm{C}$. The uncertainty in $R$ was estimated to yield an uncertainty in $S$ of $\pm 0.1 \%$. This relation assumes that the ionic composition of the salts in sea ice is identical with that of standard sea-water. There is abundant recent evidence that this is not the case (see section 7 of this paper), so that the "salinities", in common with many others quoted for sea ice from published sources, are subject to a small and indeterminate error. A 


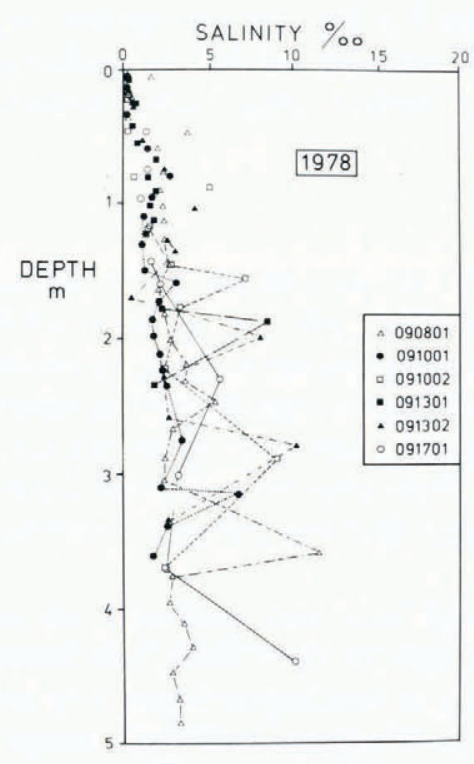

(a)

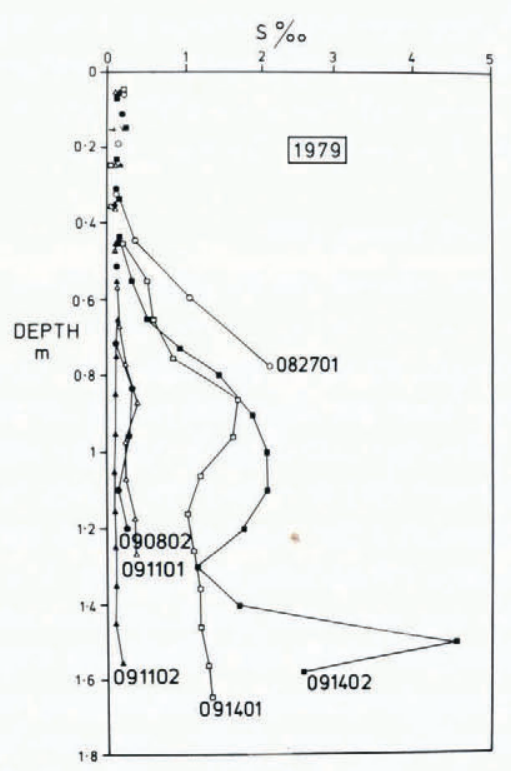

(b)

Fig. 12. Salinity profiles from multi-year cores in (a) 1978 and (b) 1979.

larger error arises from the fact that brine drainage occurs during the drawing and sectioning of the core, so that the salinities quoted are inevitably underestimates.

\subsection{Results from East Greenland $1978 / 9$}

Figure 12 shows salinity profiles from the 1978 and 1979 cores, and in Figure 13 the overall data have been averaged in groups of ten points, in order of increasing depth. The error bars are the standard deviations of depth and salinity for each group of data points. Points with salinity greater than $7 \%$ were not included in Figure 13; samples with such high salinities always

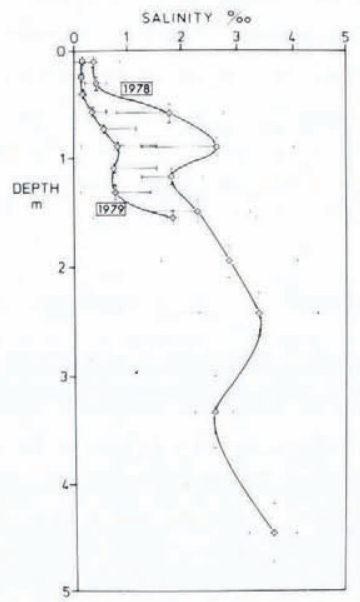

Fig. 13. Composite salinity profiles for 1978 and 1979 multi-year ice cores, averaged in groups of ten data points. Bars show standard deviation of depth and salinity for each group of points. Shaded area shows desalination during a year for floes trapped in a fjord. 
represented isolated peaks in otherwise smoothly varying salinity profiles, and consisted of thin layers of slushy ice within the fabric. It is likely that these slush layers contained sea-water which had penetrated into the floe either from the side or from below through open brine drainage channels, although they may have had frazil ice fabric during the winter, as has been seen in ice from the Weddell Sea (Gow and others, 1982) and Labrador Sea (Winsor and LeDrew, 1978).

We showed in section 2.2 that the multi-year ice sampled in Kong Oscars Fjord in 1979 came essentially from the same ensemble of floes as that sampled in 1978, because of the entrapment due to the fjord plug and the lack of replenishment from the offshore pack. The salinity profiles show a major difference between 1978 and 1979, although the 1979 profile reached only $1.7 \mathrm{~m}$ because of the difficulty of using the corer in rotten ice. Assuming that the number of cores is large enough to be an unbiased random sample, then Figure 13 shows that multi-year ice from the East Greenland Current - typified by the 1978 profile - suffers further brine drainage when confined in a fjord through the winter and part of the succeeding summer until it reached the salinity shown for the 1979 profile. The difference between the two (shaded area) is thus the brine lost from multi-year ice in a year of drainage, although under somewhat unusual conditions. Each profile in Figure 13 also displays a small increase in salinity at the upper surface - probably due to spray — and a peak of salinity at about $90 \mathrm{~cm}$ depth. This peak is also seen on the mean profile of multi-year hummocks from the Beaufort Sea (Cox and Weeks, 1974), and may represent a depth limit for flushing, which one would expect to be most effective above the waterline. In other respects the 1978 profile resembles the average profiles found by Schwarzacher (1959), in that the salinity rises to about $3 \%$ at $2 \mathrm{~m}$ depth and remains fairly constant at increasing depth, with some further increase at extreme depths near the ice-water interface.

\subsection{Results from Ymer-80}

As Figure 2(a) shows, most of the 19 cores taken during leg 1 of Ymer-80 were obtained in two probes northward into the Arctic Ocean, the first north of Nordaustlandet (cores 1-8, 10-20 July 1980) and the second north of Zemlya Frantsa Iosifa (cores 9-17, 22-28 July 1980). Core 18 was obtained west of Kvitøya on 30 July and core 19 in the Barents Sea north of Kong Karls Land on 31 July. Thus only one core comes from the Barents Sea itself; however cores 9-18 come from the zone of the Arctic Ocean which is believed to be a source area for ice which subsequently drifts down the east side of Svalbard in the weak, variable, wind-driven East Spitsbergen Current (Lunde, [1965]; Loeng and Vinje, 1979; Wadhams, 1981[a]). 13 of the cores were classed as first-year (mean thickness $1.31 \mathrm{~m}$, standard deviation $26 \mathrm{~cm}$ ) and 6 as multi-year ice (mean $2.65 \mathrm{~m}$, standard deviation $39 \mathrm{~cm}$ ).

Individual salinity profiles are given in Palosuo (1981[a], [b]), while Figure 14 shows the overall salinities for first-year ice cores averaged in groups of ten values in the same manner as Figure 13. The first-year cores show a rapid rise in salinity with increasing depth to a peak at $70 \mathrm{~cm}$, followed by a trend towards a steady value of $3-3.5 \%$. Comparison with Figure 13 (1978 data) shows

(a) similar surface salinity;

(b) a similar feature of a kink in the salinity curve at approximately the waterline $(70 \mathrm{~cm}$ for first-year, $90 \mathrm{~cm}$ for multi-year ice):

(c) a similar salinity $(3-3.7 \%$ ) in the lower part of the ice sheet.

The main difference is that the kink occurs at a higher salinity value in first-year ice, i.e. the rise 


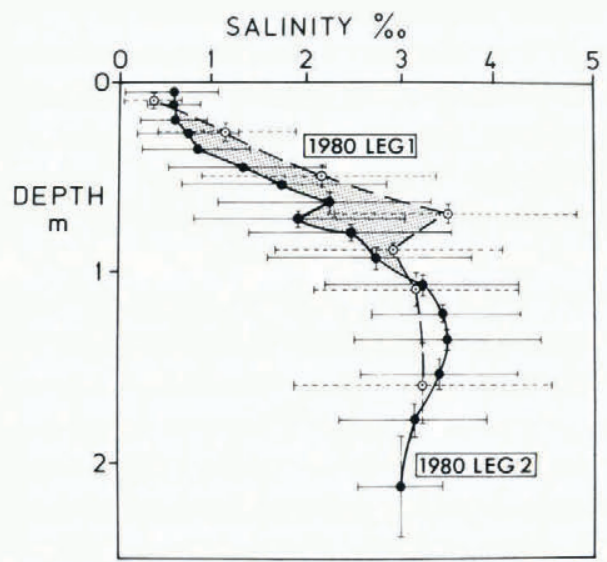

Fig. 14. Composite salinity profiles for first-year ice cores from Ymer-80, showing desalination between legs 1 and 2 .

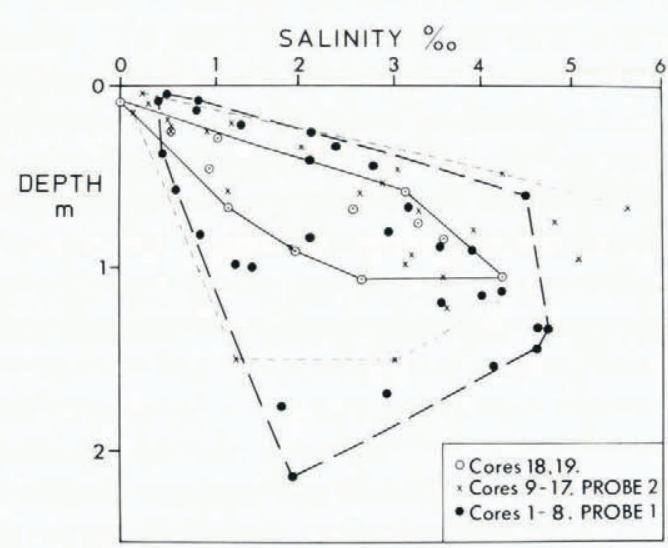

Fig. 15. Envelopes of salinity-depth for first-year cores from leg 1 of Ymer-80.

in salinity with depth is more rapid. The general form of the salinity profile is clearly that of summer, differing significantly from the salinity profile of winter first-year ice (Cox and Weeks, 1974; Weeks, 1976) where the salinity at the surface is at least as high as the salinity at depth. Figure 15, in which all of the measured salinity values are shown for the first-year profiles, indicates no significant difference between cores on the two northward probes, except for a tendency to greater desalination in the uppermost $30 \mathrm{~cm}$ during the second probe, which can be accounted for by the extra two weeks of summer experienced by the ice. Similarly, the two last cores from Kvitøya and the Barents Sea resemble the other cores.

The six multi-year cores on leg 1 comprised 29 measured salinity values, which are shown averaged in groups of 7 on Figure 16.

On leg 2 the 25 cores comprised 7 multi-year, 16 first-year, and two of indeterminate ice type. The first-year salinity profiles are shown in Figure 17, plotted on a semilogarithmic scale to emphasize variations in the uppermost low-salinity layers. The following features are apparent:

(i) The cores, with few exceptions, follow remarkably similar salinity-depth curves, suggesting that a single relationship can be used to make a good average fit to all of the first-year ice from the whole experimental region for this time of year. First-year ice from north of Fram Strait does not differ significantly from first-year ice from north of Svalbard or Zemlya Frantsa Iosifa. There are two major exceptions. A few cores (e.g. 082702,083102 ) appear to have suffered a great deal more brine drainage from their upper layers than the norm. The results from East Greenland in 1978/79 suggest that these floes may have spent the early summer in a confined waterway such as a fjord; their position north of Fram Strait would allow an origin near a European Arctic land mass. Secondly, the last two cores, taken in mid-September (091201 and 091401) are unusually saline; the reason for this is unknown.

(ii) Repeated cores from the same floe show very similar results, i.e. 090202/3, 083101/2, $082802 / 3$, showing that first-year floes in the melt season possess considerable lateral homogeneity. This is not normally the case for multi-year ice, where systematic differences exist between cores taken through hummocks and depressions (Cox and Weeks, 1974). 


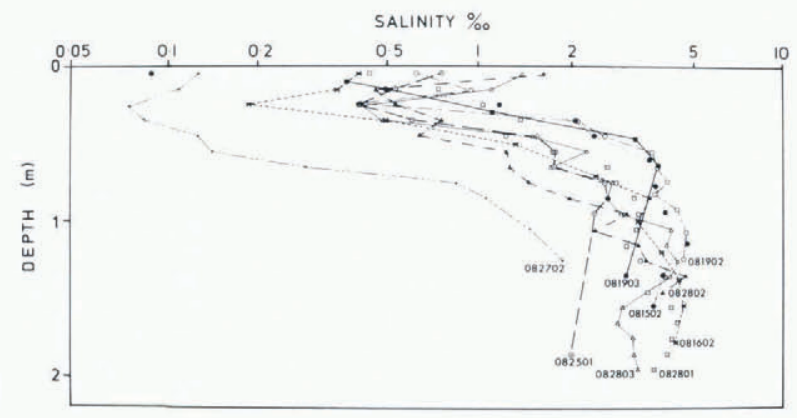

(a)

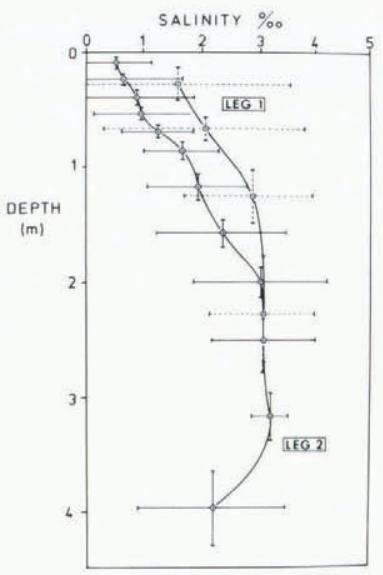

Fig. 16. Composite multi-year salinity profiles from Ymer-80, averaging over seven data points for leg 1, ten for leg 2. Note desalination between legs 1 and 2 .

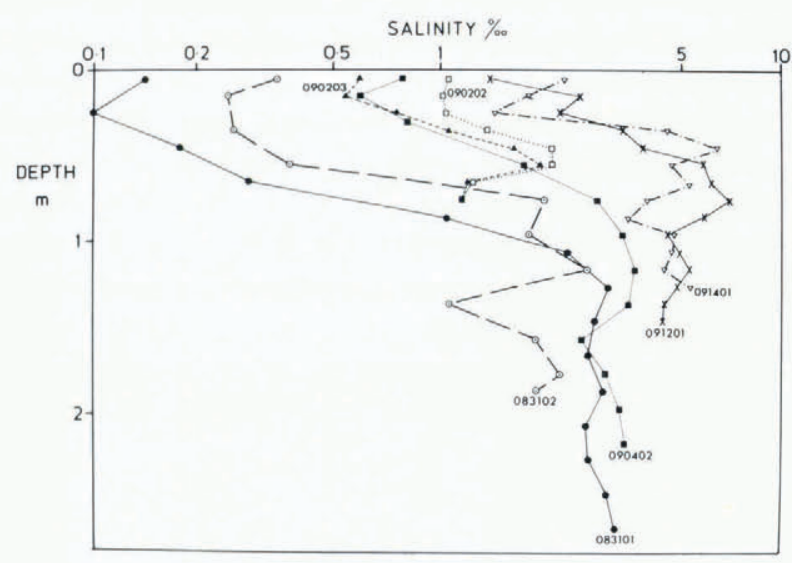

(b)

Fig. 17. Salinity profiles for first-year ice cores from leg 2 of Ymer-80, plotted on semilogarithmic scale. (a) is period 15-28 August, (b) is 31 August to 14 September.

(iii) Normally the salinity monotonically increases with depth, except in the uppermost $30 \mathrm{~cm}$ where it sometimes increases to the surface. This can be ascribed to the action of spray which is deposited on the upper surface and which percolates down through the upper layers. The large variability of salinity at the very top of the core appears to be independent of ice thickness and occurs also with multi-year ice. This raises serious difficulties in the interpretation of ice type from the results of remote-sensing techniques such as radar scatterometry (Onstott and others, 1982) which depend on the properties of the uppermost few centimetres of the ice. This may be a problem, especially in summer, throughout the marginal ice zones of the European Arctic.

A ten-point average salinity profile from the 14 first-year cores of leg 2 (excluding the 12 and 14 September cores) is shown in Figure 14. The mean salinity tends towards the same limiting value $(3-3.5 \%$ ) as for leg 1 below $1 \mathrm{~m}$, but in the uppermost metre there is more desalination. The weighted mean date for the leg 1 cores was 21 July and for leg 2 was 26 August, so the shaded area in Figure 14 represents desalination in first-year ice occurring during the $36 \mathrm{~d}$ between these dates. Again the kink is present at the waterline-a universal feature of summer salinity profiles. 


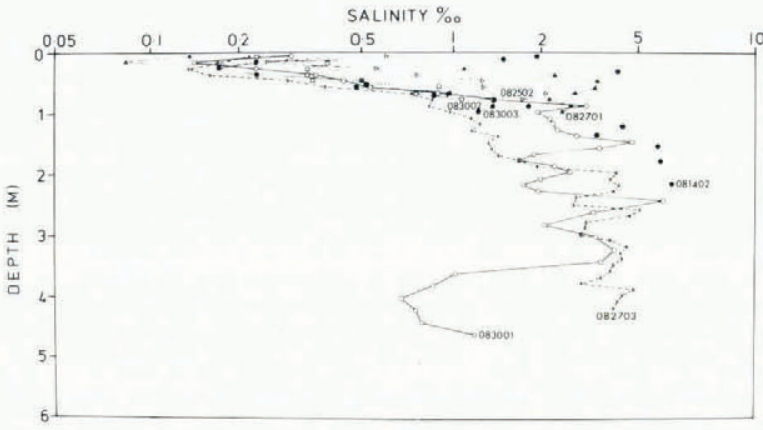

Fig. 18. Multi-year salinity profiles from leg 2 of Ymer-80, plotted on semilogarithmic scale.

Figure 18 shows the multi-year salinity profiles from leg 2, plotted on a semilogarithmic scale. There is a much greater spread of properties in the uppermost $1 \mathrm{~m}$ than in the case of firstyear ice. The only repeated cores on the same floe $(083001 / 2 / 3)$ do show very similar properties in the $20-100 \mathrm{~cm}$ range, though not in the $0-20 \mathrm{~cm}$ range, despite being sampled in wellseparated parts of a highly weathered floe. Core 083001 is of particular interest since it was taken through a floe in excess of $6.1 \mathrm{~m}$ thick (the depth limit of the corer) off the mouth of Danmarks and Independence Fjords. The floe (Fig. 19) was exceptionally weathered at the surface, with a highly developed drainage system of streams, canyons, and mesas indicating great age, and a variation in surface topography of at least $2 \mathrm{~m}$. The floe was very large, and in the

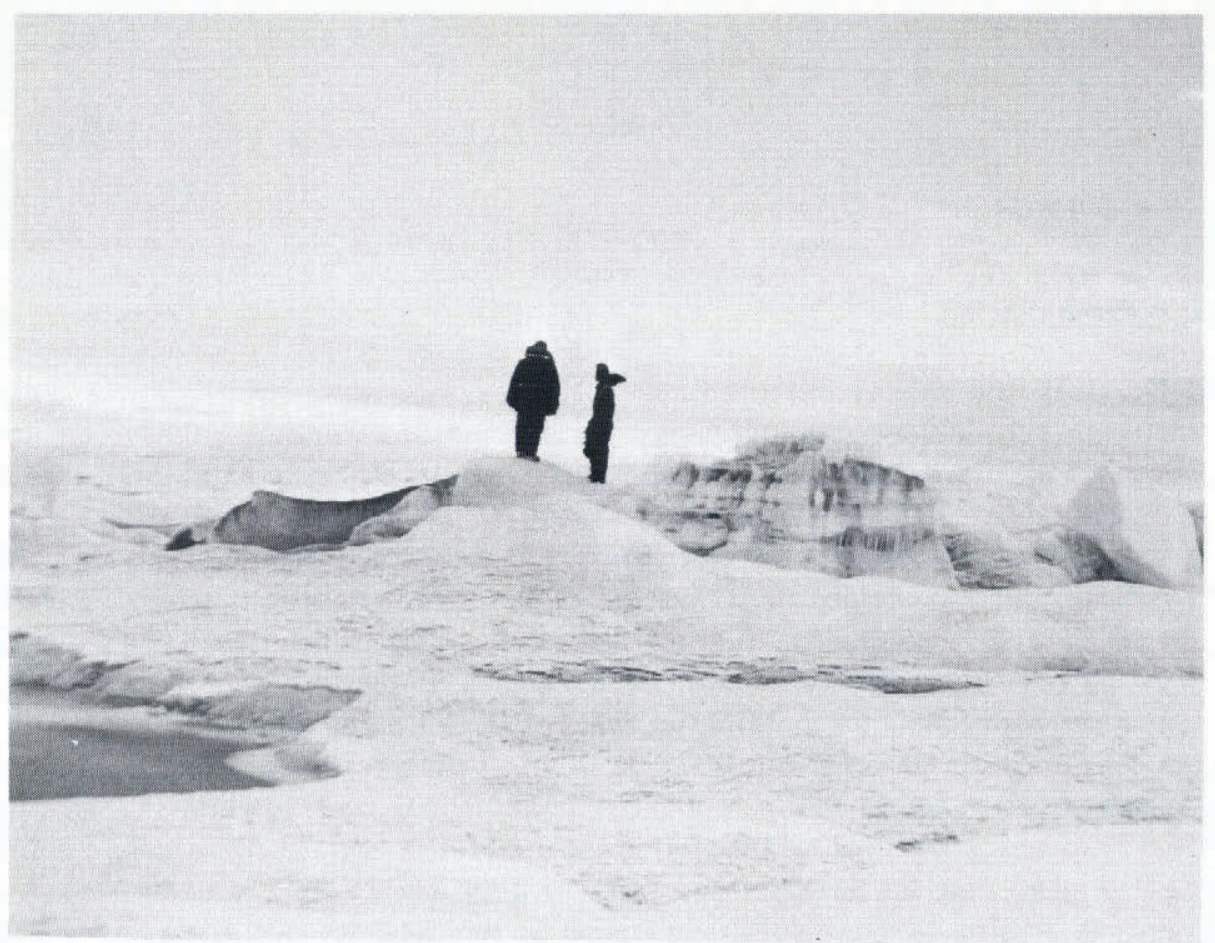

Fig. 19. Surface appearance of very old multi-year fast ice sampled at mouth of Danmarks and Independence Fjords, 30 August 1980. 
absence of aerial survey it was unclear whether the floe was actually part of the fast ice cover in the fjord mouth or whether it had recently broken out from this cover. In approaching the floe, Ymer had coasted along the fast ice edge, which had consisted of ice of a similar type. Such extremely old, very thick fast ice was called "sikussak" by Koch (1945), who described its occurrence in north-east Greenland. Walker and Wadhams (1979) collected reports of very thick floes in the Arctic Ocean and surmised that they had originated as old fast ice. Application of Maykut and Untersteiner's (1971) thermodynamic model for ice growth with altered input parameters typical of a high Arctic fjord (ocean heat flux zero, snowfall $1 \mathrm{~m}$ per year) showed that continued growth to about $20 \mathrm{~m}$ thickness could occur over tens of years, as opposed to the $3 \mathrm{~m}$ equilibrium thickness in the open ocean. The subject is further reviewed in Wadhams (1981[a]).

Figure 16 shows a composite ten-point averaged salinity profile from the leg 2 multi-year cores, compared with the averaged profile for leg 1 multi-year cores. The difference between them is considerable, and indicates the additional desalination which occurred during the period between the weighted mean dates for leg 1 (20 July) and for leg 2 (27 August). A comparison of Figures 16 and 14 shows the desalination of multi-year relative to first-year ice at the same time of year. We see a salinity which increases linearly with depth and which reaches $3 \%$ at $2 \mathrm{~m}$ instead of $1 \mathrm{~m}$ for the first-year profile. A comparison of Figures 16 and 13 shows a good correspondence between the 1980 leg 2 multi-year curve and the 1978 multi-year curve, except that the kink is smoothed out in the 1980 profile. This indicates that the 1978 profile from East Greenland was indeed typical of multi-year ice from the offshore pack and that therefore summer multi-year ice has a similar salinity structure in the low latitude $\left(72^{\circ}\right)$ East Greenland Current as it does in the Trans-Polar Drift Stream north of Fram Strait and Svalbard.

\subsection{Average salinity}

Cox and Weeks (1974) found a negative correlation between the average salinity $\bar{S}$ through the depth of the ice sheet and the ice thickness $h$ in winter and a weak positive correlation in summer. Figure 20 shows $\bar{S}$ plotted against $h$ for all of the cores which were sampled to the bottom. There is again a weak positive correlation with a linear regression

$$
\bar{S}=2.04+0.25 h \quad(r=0.27)
$$

compared with Cox and Weeks' result of

$$
\bar{S}=1.58+0.18 h \quad(r=0.25) .
$$

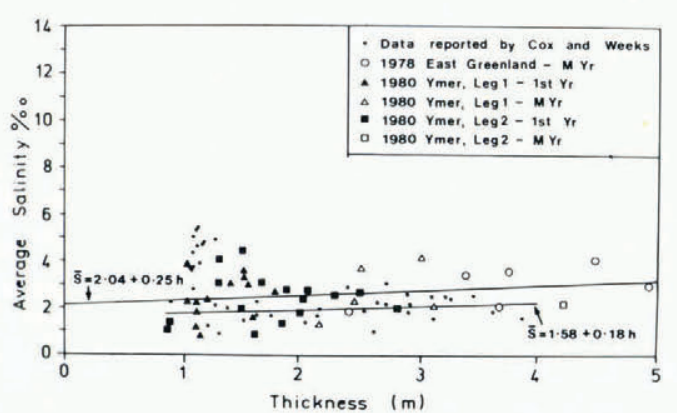

Fig. 20. Average salinity plotted against ice thickness for all 1978-80 cores sampled to bottom. Data reported by Cox and Weeks (1974) are also shown. Upper regression line fits our data; lower is from Cox and Weeks. 
Our composite salinity profiles lead us to expect a positive correlation between $\bar{S}$ and $h$ for a given ice type (first-year or multi-year). However, this effect is masked by the fact that multi-year ice is more desalinated in its upper layers than first-year ice, so that Figure 20 is really a sum of two independent lines of positive gradient, one for first-year ice and the other (with a lower intercept) for multi-year ice. In fact, if separate linear regressions for the first-year and multi-year points in Figure 20 are carried out, the multi-year data show a stronger positive correlation with depth of

$$
\bar{S}=1.59+0.37 h \quad(r=0.35)
$$

while the first-year data show a very weak correlation:

$$
\bar{S}=2.15+0.19 h \quad(r=0.10) .
$$

\section{Temperature structure}

Temperature profiles are available only from the 1978 and 1979 data, since temperature was not recorded during leg 1 of Ymer-80, and a fault was found in the temperature measuring equipment during leg 2. Figure 21 is a composite plot of all of the temperature data from 1978/79; a typical profile is shown in Figure 25. It can be seen that in 1978 there was a tendency towards a linear temperature gradient between a bottom at about $-1.8^{\circ} \mathrm{C}$ and a top surface in the region of $-1{ }^{\circ} \mathrm{C}$ to $0{ }^{\circ} \mathrm{C}$. This fits the observed ocean and atmospheric data (section 2.1) which showed that the floes were normally in water which was at or near the freezing point, while their top surface was exposed to intense solar radiation despite a slightly sub-zero air temperature. In 1979, with a single exception, all of the cores were isothermal with a temperature of about $-0.6^{\circ} \mathrm{C}$, supporting the conclusion that they were rotting throughout their depth on account of immersion in warm water (Fig. 4).

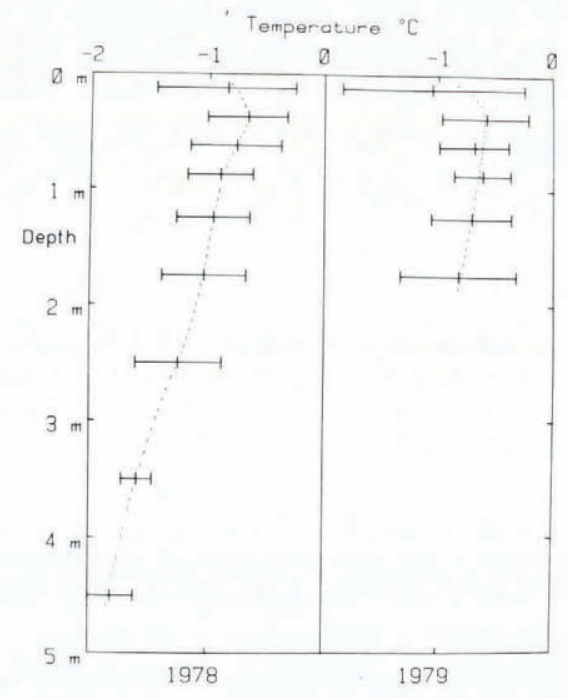

Fig. 21. Composite temperature profiles from 1978 and 1979 multi-year cores.

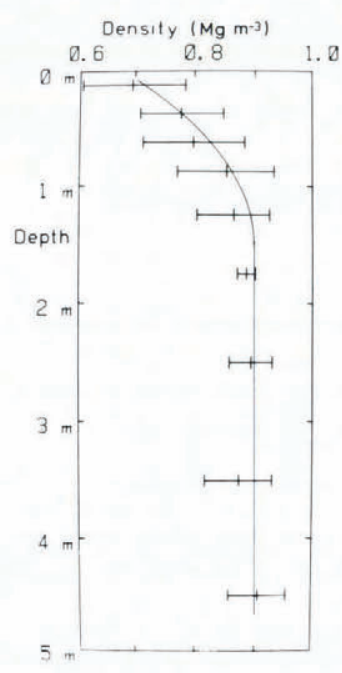

Fig. 22. Composite density profile from 1978 and 1979 multi-year cores. 


\section{Density}

The method used to measure density, i.e. weighing combined with caliper measurements of dimensions, can be expected to give a wide scatter. All of the data from 1978/79 (none available from 1980) have therefore been combined in a composite curve, Figure 22, by averaging in groups of ten points. A smooth curve has been fitted to these data, of form

$$
\begin{array}{ll}
\rho=0.53+0.074 \ln z & 1 \leqslant z \leqslant 150, \\
\rho=0.9 & 150<z
\end{array}
$$

where $\rho$ is specific gravity, and $z$ is depth in $\mathrm{cm}$ measured downwards from the surface. The logarithmic form excludes the topmost centimetre. This is not held to be a general result.

\section{BRINE VOLUME AND DIELECTRIC PROPERTIES}

The complex dielectric constant of sea ice depends strongly on the brine volume of the ice, and less strongly on the density. Using the salinity and temperature curves for 1978/79 data the relative brine volume was calculated using the relationships of Frankenstein and Garner (1967). The following standard values were taken for salinity and temperature variation with depth and used to compute brine volume $v$ (Table I). In 1978 the brine volume increased with depth to a peak at about $2 \mathrm{~m}$ followed by a slight decline as the decreasing temperature offset the increasing salinity. In 1979 the brine volume increased radically with increasing depth and we presume that this saturation of the ice with brine continued to the bottom. What strength there was in the ice was therefore most likely confined to its upper portions.

On the basis of measurements on both first-year and multi-year ice cores obtained in the AIDJEX experiment, Vant (unpublished) proposed an empirical model for the complex dielectric constant, of form

$$
\varepsilon_{\mathrm{r}}=a_{0}+a_{1} v
$$

where $\varepsilon_{\mathrm{r}}$ is the dielectric constant (imaginary or real part), $v$ is the relative brine volume and the constants $a_{0}$ and $a_{1}$ are fitted to the data measured at the AIDJEX experiment. The constants

\begin{tabular}{|c|c|c|c|c|c|c|}
\hline $\mathrm{I}_{\mathrm{A}}$ & $\mathrm{D}$ & $\begin{array}{r}\text { VOLUN } \\
\text { ML }\end{array}$ & $\begin{array}{l}\text { ROM } \\
\text { YEAR }\end{array}$ & POSITE & $1 \mathrm{~A}$ & \\
\hline & & 1978 & & & 1979 & \\
\hline$z$ & $T$ & $S$ & $v$ & $T$ & $S$ & $v$ \\
\hline $\mathrm{m}$ & ${ }^{\circ} \mathrm{C}$ & $\%$ & $\%$ & ${ }^{\circ} \mathrm{C}$ & $\%$ & $\%$ \\
\hline 0 & -1 & 0.2 & 10 & -0.7 & 0.1 & 7 \\
\hline 0.5 & -1 & 1.3 & 65 & -0.5 & 0.3 & 31 \\
\hline 1 & -1 & 1.8 & 91 & -0.5 & 1.0 & 103 \\
\hline 2 & -1.2 & 2.4 & 100 & -0.5 & 2.3 & 237 \\
\hline 3 & -1.4 & 2.7 & 95 & & & \\
\hline 4 & -1.6 & 3.0 & 91 & & & \\
\hline 5 & -1.9 & 3.2 & 81 & & & \\
\hline
\end{tabular}
were calculated for first-year ice, multi-year ice and artificially grown ice, as well as for both the real part and the imaginary part of the complex dielectric constant. 
TABle II. Dielectric CONSTANT FOR MUlti-year ICE (after Vant, unpublished)

$\begin{array}{cccc}\begin{array}{c}\text { Frequency } \\ \mathrm{GHz}\end{array} & a_{0} & a_{1} & \varepsilon_{\mathrm{r}}^{\prime} \\ 0.1 & 0.022 & 6.66 & 3.12 \\ 0.4 & -0.058 & 12.01 & 3.23 \\ 0.8 & 0.0 & 4.74 & 3.11 \\ 1.0 & -0.004 & 4.36 & 3.10 \\ 2.0 & 0.013 & 4.35 & 3.06 \\ 4.0 & -0.007 & 2.99 & 3.01\end{array}$

Table II shows $a_{0}$ and $a_{1}$ as a function of frequency for multi-year ice and for the imaginary part of the dielectric constant $\varepsilon_{\mathrm{r}}^{\prime \prime}$. The table also shows Vant's measurements of $\varepsilon_{\mathrm{r}}^{\prime}$, which he found to be independent of brine volume.

The values of $\varepsilon_{\mathrm{r}}^{\prime}$ vary only slightly with frequency, with a peak at $0.4 \mathrm{GHz}$. Evans (1965) found an experimental relationship between $\varepsilon_{\mathrm{r}}^{\prime}$ and the specific gravity $\rho$ of glacier ice as follows:

$$
\left(\varepsilon_{\mathrm{r}}^{\prime}\right)^{1 / 2}=1+0.88 \rho \text {. }
$$

When $\rho=0.9, \varepsilon_{\mathrm{r}}^{\prime}$ is 3.12 , which agrees well with Vant's values. Thus the real part of the dielectric constant for multi-year ice is similar to that for glacial ice.

Table II shows a strong peak for $\varepsilon_{\mathrm{r}}^{\prime \prime}$ at $0.4 \mathrm{GHz}$. This has not been reported elsewhere in the literature. If we ignore it we can fit an exponential distribution to the rest of the data in Table II to give the following empirical method of obtaining $\varepsilon_{\mathrm{r}}^{\prime \prime}$ from $v$ (in \%o) and frequency $f$ (in $\mathrm{GHz}$ ):

$$
\varepsilon_{\mathrm{r}}^{\prime \prime}=7.44 \times 10^{-3} v \exp (-0.25 \mathrm{f})
$$

This relationship is plotted in Figure 23, which enables dielectric constant to be computed for the brine volume values of Table I.

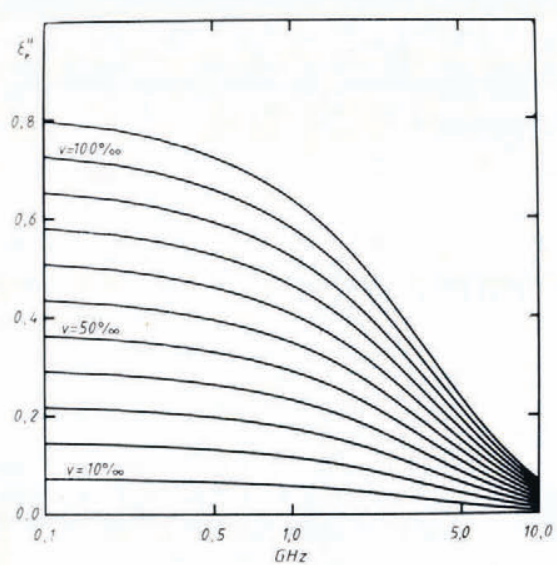

Fig. 23. Imaginary part $\left(\varepsilon_{\mathrm{r}}^{\prime \prime}\right)$ of complex dielectric constant as a function of frequency for brine volumes from 10 to $110 \%$, calculated from empirical equation for multi-year ice in summer.

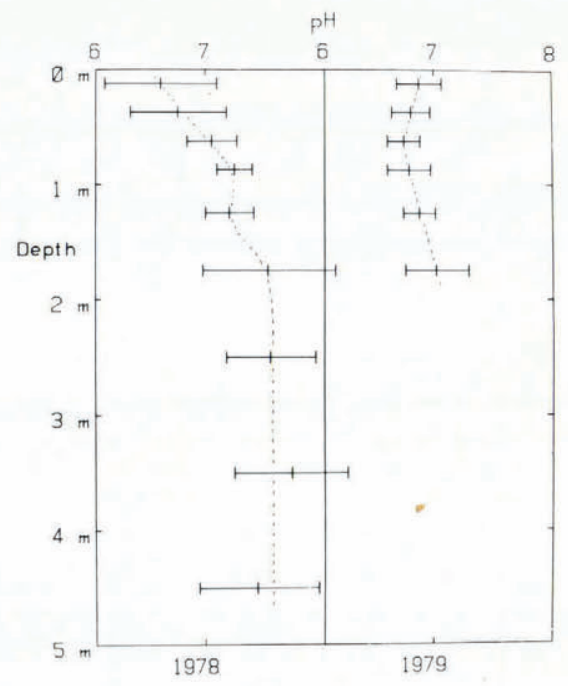

Fig. 24. Composite pH profiles from 1978 and 1979 multi-year cores. 


\section{7. $\mathrm{pH}$ AND IONIC COMPOSITION}

Composite $\mathrm{pH}$ data from 1978 and 1979 cores are plotted in Figure 24, averaged in groups of ten measured values in order of depth. In the 1978 cores the deeper part of the ice shows a $\mathrm{pH}$ value of about 7.6, only slightly below the normal range for sea-water ( 7.8 to 8.3 ) in the open ocean. In the upper parts of the cores, however, there is a significant trend to acidity. The 1979 cores, by contrast, have a nearly neutral $\mathrm{pH}$ throughout, possibly due to the very low salt content (Fig. 13).

Figure 25 shows a single profile of salinity, temperature, density, and $\mathrm{pH}$ from a 1978 multiyear core. In common with other cores this shows a very strong positive correlation between $\mathrm{pH}$ variations and salinity variations down the length of the core. The correlation between absolute $\mathrm{pH}$ and absolute salinity (or conductivity) is less strong, but is still positive (Fig. 26). Sea-water behaves as a buffer, because of the excess of cations over anions and the effect of carbonate and borate content. As Figure 26 shows, the $\mathrm{pH}$ of sea-water samples from the surface waters of Kong Oscars Fjord and the offshore East Greenland Current varied little through a considerable range of salinity. The much larger variations in sea-ice $\mathrm{pH}$, especially the positive correlation with salinity, indicate that sea-ice melt water does not act as a buffer in the same way.

A core taken on 14 August 1979 has been analysed for $\mathrm{SO}_{4}^{--}, \mathrm{Cl}^{-}, \mathrm{Ca}^{++}$, and $\mathrm{Mg}^{++}$ concentrations. Due to the limited content of $\mathrm{Ca}^{++}$and $\mathrm{Mg}^{++}$, these two constituents cannot be distinguished, but only the sum of the two is measured. In sea-water the ratios between the molarities of dissolved $\mathrm{SO}_{4}^{--}, \mathrm{Cl}^{-}, \mathrm{Ca}^{++}$and $\mathrm{Mg}^{++}$are constant (in the open oceans) and the ratios are

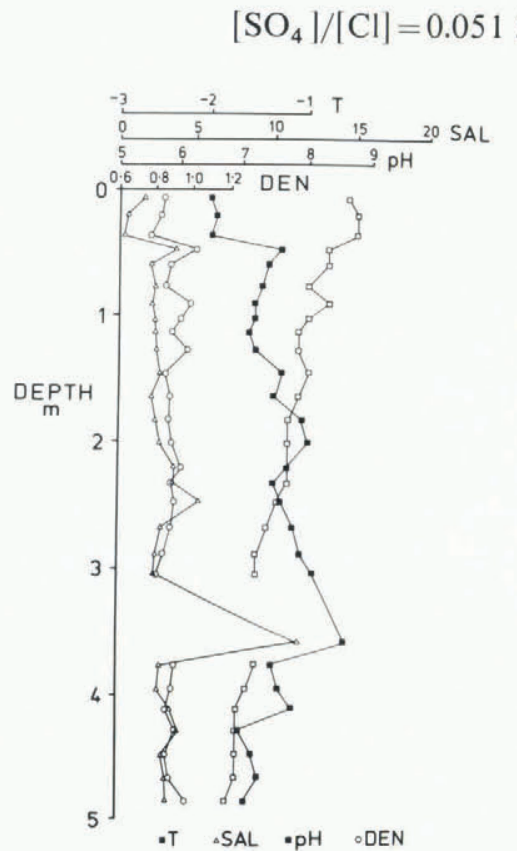

Fig. 25. Core 090801, taken on 8 September 1978 , showing salinity, temperature, density and $\mathrm{pH}$. Note close correspondence between salinity and $\mathrm{pH}$ variations.

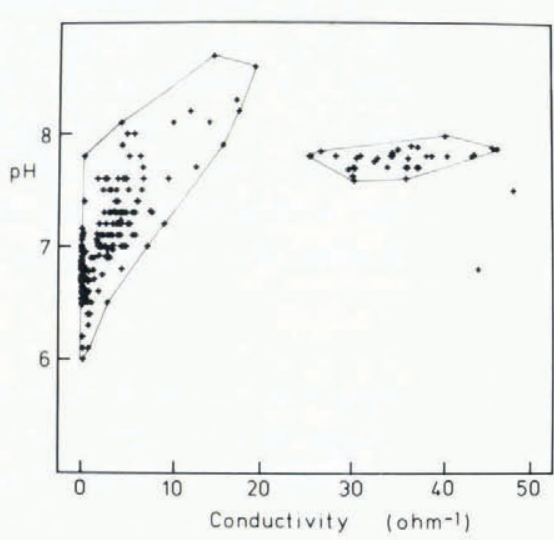

Fig. 26. pH plotted against conductivity for 1978 and 1979 cores (left envelope) and surface sea-water samples (right envelope; and two isolated points). 


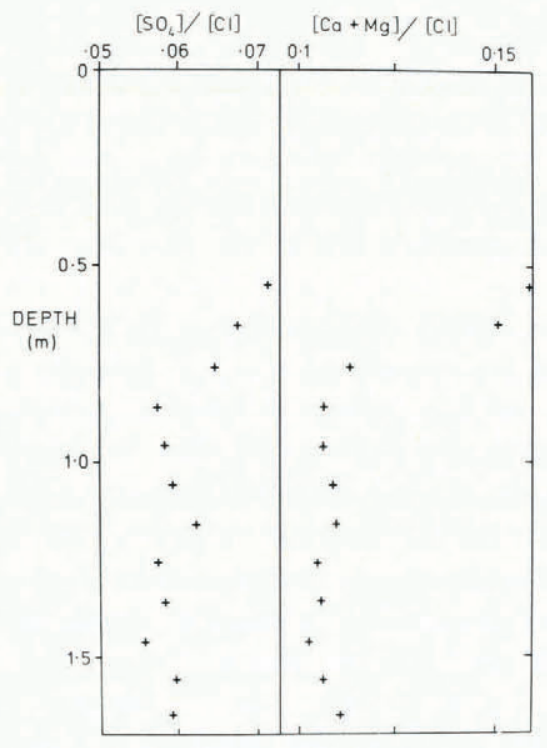

Fig. 27. Ionic ratios for a core taken on 14 August 1979.

In Figure 27 the same ratios for the analysed ice core are plotted as a function of depth below the ice surface. From Figure 27 it is seen that in the deeper part of the ice the ratio of $\left[\mathrm{SO}_{4}\right] /[\mathrm{Cl}]$ is slightly higher (0.058) than for sea-water and the ratio of $[\mathrm{Ca}+\mathrm{Mg}] /[\mathrm{Cl}]$ is slightly lower (0.108) than for sea-water. Above approximately $80 \mathrm{~cm}$ depth both ratios increase rapidly indicating that the content of chloride is decreasing.

Doronin and Kheysin (1975) claimed that brine drainage alters the ionic composition of the salts in sea ice. For instance, below $-8.2{ }^{\circ} \mathrm{C}$ sodium sulphate precipitates from the brine in any isolated brine cell, and if the remaining brine subsequently drains from the ice, the salt remaining will contain an excess of sodium and sulphate ions. As well as altering the $\mathrm{pH}$, such effects would alter the conductivity/salinity relationship from that prevailing for sea-water (Equation (2)). Further, the chlorinity/salinity relationship would be altered. The chloride ion has a high equivalent conductivity relative to the other constituents of sea-water or melted ice, so the equivalent conductivity of sea-water is highly sensitive to variations in the relative concentration of chloride. The $\mathrm{pH}$ data and the data of Figure 27 clearly demonstrate that salts retained in sea ice suffer a change in ionic composition. For high accuracy in determining the salinity of sea ice samples, it is therefore necessary to use density measurements.

\section{Conclusions}

Since ice coring was not the primary purpose of these three field operations, the results are not as comprehensive as one would hope. Nevertheless, the lack of ice data from this part of the Arctic makes it worthwhile to present what has been obtained. The main conclusion is that ice from the European Arctic does not differ significantly in salinity characteristics from Beaufort Sea ice in summer, except under special circumstances such as confinement in a fjord or many years of growth as fast ice.

By averaging the results from many cores we have been able to demonstrate 
(i) the form of the mean first-year and multi-year ice salinity profiles at the end of the melt season;

(ii) the degree of desalination occurring in first-year and multi-year ice over a five-week period (21 July to 26 August);

(iii) the additional desalination occurring in multi-year ice which has been confined in a fjord for a winter and exposed to warm water for a period in early summer;

(iv) the form of a salinity profile in sikussak, or old multi-year fast ice;

(v) the relationship between average salinity and ice thickness in summer.

In addition we have found that the $\mathrm{pH}$ of sea ice differs from that of sea-water; sea ice does not behave as a buffer, and the $\mathrm{pH}$ increases with conductivity. Direct measurements of ionic composition show that this, too, differs from the composition of sea-water, indicating a relative lack of chloride ion. This will affect salinity measurements made by the conductivity technique.

With respect to ice topography, we have found that in the northern Barents Sea in summer both the mean ice thickness and the ridging density are considerably lower than in the central Arctic.

\section{ACKNOWLEDGEMENTS}

The field operations described here, and the collection and analysis of the ice-core data, involved many scientists besides the authors. The personnel who took part in the field trips were: 1978: P. W.; S. O.; Dr D. J. Goodman (Cavendish Laboratory, Cambridge, now with B.P. Trading Ltd, London); S. C. Moore (S.P.R.I.): O. Christiansen (Danmarks Tekniske Højskole in remote-sensing aircraft).

1979: P. W.; S. O.; Dr V. A. Squire, S. C. Moore, A. M. Cowan (S.P.R.I.); K. K. Hansen (Danmarks Tekniske Højskole, in remote-sensing aircraft).

1980, leg 1: M. L.; Dr E. Palosuo (University of Helsinki).

1980, leg 2: P. W.; Dr V. A. Squire, S. C. Moore (S.P.R.I.); R. G. Onstott (University of Kansas Centre for Research, Lawrence, Kansas).

Our thanks are due also to the organizers of Ymer-80 (with scientific funding from Naturvetenskapliga forskningsrådet, the Swedish Natural Science Research Council); Professor V. Schytt; the officers, crew and scientists of Ymer; and the helicopter pilots of Greenlandair and the Swedish Navy. For support for the experiments we are grateful to the Office of Naval Research under contracts N00014-78-G-0003 and N00014-80-G-0002; the Natural Environment Research Council of Great Britain; British Petroleum Co Ltd; the Danish Natural Science Research Council; the Meteorological Institute, Copenhagen, for aircraft support; and the Finnish Board of Navigation. We thank Rob Massom for diagrams.

MS. received 2 April 1982

\section{REFERENCES}

Cox, G.F.N., and Weeks, W. F. 1974. Salinity variations in sea ice. Journal of Glaciology, Vol. 13, No. 67. p. $109-20$. Doronin, Yu. P., and Kheysin, D. E. 1975. Morskoy led. Leningrad, Gidrometeoizdat. [English translation: Sea ice. Translated by Y. V. Kathavate. Edited by V. S. Kothekar. Rotterdam, A. A. Balkema, [ ${ }^{\mathrm{C}}$ 1977].]

Evans, S. 1965. Dielectric properties of ice and snow-a review. Journal of Glaciology, Vol. 5, No. 42, p. $773-92$.

Frankenstein, G., and Garner, R. 1967 . Equations for determining the brine volume of sea ice from $-0.5^{\circ}$ to $-22.9^{\circ} \mathrm{C}$. Journal of Glaciology, Vol. 6, No. 48, p. 943-44.

Goodman, D. J., and others. 1980. The flexural response of a tabular ice island to ocean swell. by D. J. Goodman. P. Wadhams, and V. A. Squire. Annals of Glaciology, Vol. 1, p. 23-27. 
Gow, A. J., and others. 1982. Physical and structural characteristics of Antarctic sea ice, by A. J. Gow, S. F. Ackley, W. F. Weeks, and J. W. Govoni. Annals of Glaciology, Vol. 3, p. 113-17.

Hibler, W. D., III. 1980. Modeling a variable thickness sea ice cover. Monthly Weather Review, Vol. 108, No. 12, p. $1943-73$.

Hibler, W. D., III, and others. 1974. Classification and variation of sea ice ridging in the western Arctic basin, by W. D. Hibler III and S. J. Mock, W. B. Tucker III. Journal of Geophysical Research, Vo. 79, No. 18, p. $2735-43$.

Koch, L. 1945. The East Greenland ice. Meddelelser om Grønland, Bd. 130, Nr. 3.

Leppäranta,. M., and Palosuo, E. [1981.] Studies of sea ice ridging with a ship-borne laser profilometer, POAC 81: the sixth International Conference on Port and Ocean Engineering under Arctic Conditions, Quebec, Canada, July 27-31, 1981. Proceedings, Vol. 2, p. 1031-38.

Loeng, H., and Vinje, T. E. 1979. On the sea ice conditions in the Greenland and Barents Seas. POAC 79: the fifth International Conference on Port and Ocean Engineering under Arctic Conditions. At the Norwegian Institute of Technology. August 13-18, 1979. Proceedings, Vol. 1, p. 163-76.

Lunde, T. [1965.] Ice conditions at Svalbard 1946-1963. Norsk Polarinstitutt. Arbok, 1963, p. 61-80.

Maykut, G. A., and Untersteiner, N. 1971. Some results from a time-dependent, thermodynamic model of sea ice. Journal of Geophysical Research, Vol. 76. No. 6, p. 1550-75.

Norsk Meteorologisk Institutt. 1980. Iskart, månedsmiddel juli 1980. Oslo, Norsk Meteorologisk Institutt.

Onstott, R. G., and others. 1982. Four years of low altitude sea ice broadband backscatter measurements, by R. G. Onstott, R. K. Moore, S. Gogineni, and C. V. Dalker. Ocean Engineering, Vol.. OE-7, No. 1, p. 44-50.

Overgaard, S. 1980. Multi-year sea ice investigation in the East Greenland Current. Technical University of Denmark. Electromagnetics Institute, Internal Report R228.

Palosuo, E. [1981][a]. The biologically important areas in the Arctic Ocean. POAC 81: the sixth International Conference on Port and Ocean Engineering under Arctic Conditions, Québec, Canada, July 27-31, 1981. Proceedings, Vol. 2, p. 902-11.

Palosuo, E. 1981[b]. Isarna kring Ymer-juli 1980. Ymer, 101. Årg., p. 46-50.

Schwarzacher, W. 1959. Pack-ice studies in the Arctic Ocean. Journal of Geophysical Research, Vol. 64, No. 12, p. $2357-67$.

UNESCO. 1971. International oceanographic tables. Vol. 1. Paris, UNESCO; Wormley, National Institute of Oceanography of Great Britain.

Vant, M. R. Unpublished. A combined empirical and theoretical study of the dielectric properties of sea ice over the frequency range $100 \mathrm{MHz}$ to $4 \mathrm{GHz}$. [Ph.D. thesis, Carleton University, Ottawa, 1976.]

Vinje, T. E. 1981. Frequency distribution of sea ice in the Greenland and Barents Seas, 1971-1980. Norsk Polarinstitutt. Arbok, 1980, p. 57-61.

Wadhams, P. 1979. Field experiments on wave-ice interaction in the Labrador and East Greenland Currents, 1978. Polar Record, Vol. 19, No. 121, p. 373-76.

Wadhams, P. 1980. Ice characteristics in the seasonal sea ice zone. Cold Regions Science and Technology, Vol. 2, p. $37-87$.

Wadhams, P. 1981[a]. The ice cover in the Greenland and Norwegian Seas. Reviews of Geophysics and Space Physics, Vol. 19, No. 3, p. 345-93.

Wadhams, P. 1981[b]. Sea-ice topography of the Arctic Ocean in the region $70^{\circ} \mathrm{W}$ to $25^{\circ}$ E. Philosophical Transactions of the Royal Society of London, Ser. A, Vol. 302, No. 1464, p. 45-85.

Wadhams. P., and Squire, V. A. 1979. Field experiments on wave-ice interaction in the Bering Sea and Greenland waters, 1979. Polar Record, Vol. 20, No. 125, p. 147-58.

Wadhams, P., and Squire, V. A. In press. An ice-water vortex at the edge of the East Greenland Current. Journal of Geophysical Research, Vol. 88.

Walker, E. R., and Wadhams, P. 1979. Thick sea-ice floes. Arctic, Vol. 32, No. 2, p. 140-47.

Weeks, W. F. 1976. Sea ice conditions in the Arctic, AIDJEX Bulletin, No. 34, p. 173-206.

Weeks, W. F. 1982. The physical properties of the sea ice cover of the Greenland Sea, CRREL Special Report (Hanover, N. H.) 82-28.

Winsor, W. D., and LeDrew, B. R. 1978. Ice feature characterization-Labrador offshore. C-CORE Publication (Memorial University of Newfoundland. Centre for Cold Ocean Resources Engineering) 78-4. (Project SAR '77. Field Data Report No. 14.)

Ymer. 1981. Expedition Ymer-80. Ymer, 101. Årg.

Zubov, N. N. 1945, L'dy Arktiki [Arctic ice]. Moscow, Izdatel'stvo Glavsermorputi. 